Article

\title{
Mapping Irrigated Areas Using MODIS 250 Meter Time-Series Data: A Study on Krishna River Basin (India)
}

\author{
Murali Krishna Gumma ${ }^{1, *}$ Prasad S. Thenkabail ${ }^{2}$ and Andrew Nelson ${ }^{1}$ \\ 1 International Rice Research Institute, Los Banos 7777, Philippines; E-Mail: a.nelson@irri.org \\ 2 Southwest Geographic Science Center, U.S. Geological Survey, 114, W. Separation Canyon Trl., \\ Flagstaff, AZ 86001, USA; E-Mail: pthenkabail@usgs.gov \\ * Author to whom correspondence should be addressed; E-Mail: m.gumma@irri.org, \\ muraligk5@gmail.com; Tel.: +63-2-580-5600 ext. 2627; Fax: +63-2-580-5699.
}

Received: 1 December 2010; in revised form: 30 December 2010 / Accepted: 7 January 2011 / Published: 13 January 2011

\begin{abstract}
Mapping irrigated areas of a river basin is important in terms of assessing water use and food security. This paper describes an innovative remote sensing based vegetation phenological approach to map irrigated areas and then the differentiates the ground water irrigated areas from the surface water irrigated areas in the Krishna river basin (26,575,200 hectares) in India using MODIS 250 meter every 8-day near continuous time-series data for 2000-2001. Temporal variations in the Normalized Difference Vegetation Index (NDVI) pattern obtained in irrigated classes enabled demarcation between: (a) irrigated surface water double crop, (b) irrigated surface water continuous crop, and (c) irrigated ground water mixed crops. The NDVI patterns were found to be more consistent in areas irrigated with ground water due to the continuity of water supply. Surface water availability, on the other hand, was dependent on canal water release that affected time of crop sowing and growth stages, which was in turn reflected in the NDVI pattern. Double cropped and light irrigation have relatively late onset of greenness, because they use canal water from reservoirs that drain large catchments and take weeks to fill. Minor irrigation and ground water irrigated areas have early onset of greenness because they drain smaller catchments where aquifers and reservoirs fill more quickly. Vegetation phonologies of 9 distinct classes consisting of Irrigated, rainfed, and other land use classes were also derived using MODIS 250 meter near continuous time-series data that were tested and verified using groundtruth data, Google Earth very high resolution (sub-meter to 4 meter) imagery, and state-level census data. Fuzzy classification accuracies for most
\end{abstract}


classes were around $80 \%$ with class mixing mainly between various irrigated classes. The areas estimated from MODIS were highly correlated with census data (R-squared value of 0.86).

Keywords: ground water irrigated areas; MODIS; NDVI; irrigated areas; Krishna Basin

\section{Introduction}

In the Krishna river basin, the fourth largest river basin in India with basin area of 26,575,200 hectares, changes in the irrigated areas are frequent. Major canal irrigation schemes often suffer from inequitable distribution of water due to over-use in head reaches which is partly caused by farmer preferences to water intensive crops like rice and sugarcane [1,2]. However, farmers often supplement and/or exclusively use ground water irrigation. Ground water irrigation, in particular, has become increasingly common globally. In India, the total ground water irrigated area even exceeds the surface water irrigated area [3,4]. Most ground water irrigated plots are small ( $<1$ ha), which complicates use of traditional satellite image classification techniques [5,6]. However, quite often these small plots adjoin each other one after the other with each plot having a well providing contiguity. Nevertheless, identification of training sites for supervised classifications is particularly problematic in areas with patchy irrigated systems, where plot sizes are often small relative to satellite pixels.

Due to multi-cropping and varying cropping calendars, single image snap-shots often do not adequately characterize irrigated areas [7]. Many crops have relatively short and staggered growth, development, and senescent phases, making accurate mapping difficult using satellite images from a single or even a series of overpasses. Satellite data with short return intervals, such as daily Moderate Resolution Imaging Spectrometer (MODIS) imagery and their 8-day processed cloud-free composites e.g., MOD09Q1 data product [8], have distinguishing the full variety of cropping patterns and irrigation intensities (including Ground water and surface water).

This paper presents maps of land cover and irrigated in a heterogeneous landscape using an irrigated fraction approach. The method fuses and compares multiple data sources, including a time-series of MODIS imagery, groundtruth data, and agricultural census data. We first generate generalized classes of land cover using unsupervised classification of a time-series of MODIS NDVI images. We then estimate irrigated fractions and total irrigated area for each remote sensing class using groundtruth data, and agricultural census data. Accuracy assessment is performed by comparing the irrigated fraction statistics determined by each data source, and by fuzzy accuracy assessment based on groundtruth data [9]. The main innovations of the method include use of NDVI time-series to differentiate areas irrigated by surface water and ground water, and the use of multiple data sources for aggregate accuracy assessment. 


\section{Study Area}

The Krishna Basin (Figure 1) is India's fourth largest river basin and covers 26,575,200 of southern India, traversing the states of Karnataka $\left(116,247 \mathrm{~km}^{2}\right)$, Andhra Pradesh $\left(78,256 \mathrm{~km}^{2}\right)$ and Maharashtra $\left(71,249 \mathrm{~km}^{2}\right)$. The basin is relatively flat, except for the Western Ghats and some forested hills in the centre and northeast.

The River Krishna originates in the Western Ghat mountains, flows east across the Deccan Plateau, and discharges into the Bay of Bengal. It has three main tributaries that drain from the northwest, west, and southwest (Figure 1). The climate is semi-arid, with some dry, sub-humid areas in the eastern delta and humid areas in the Western Ghats. Annual precipitation averages $780 \mathrm{~mm}$ and decreases gradually from $850-1,000 \mathrm{~mm}$ in the Krishna Delta to $300-400 \mathrm{~mm}$ in the northwest, then increases to $>1,000 \mathrm{~mm}$ in the Western Ghats (Figure 1). In the extreme western parts of the basin, the Western Ghats have high annual precipitation (1,500-2,500 $\mathrm{mm})$. Most of the rainfall occurs during the monsoon from June to October.

Figure 1. The Krishna River Basin (River network extracted from SRTM 90m DEM [10]).

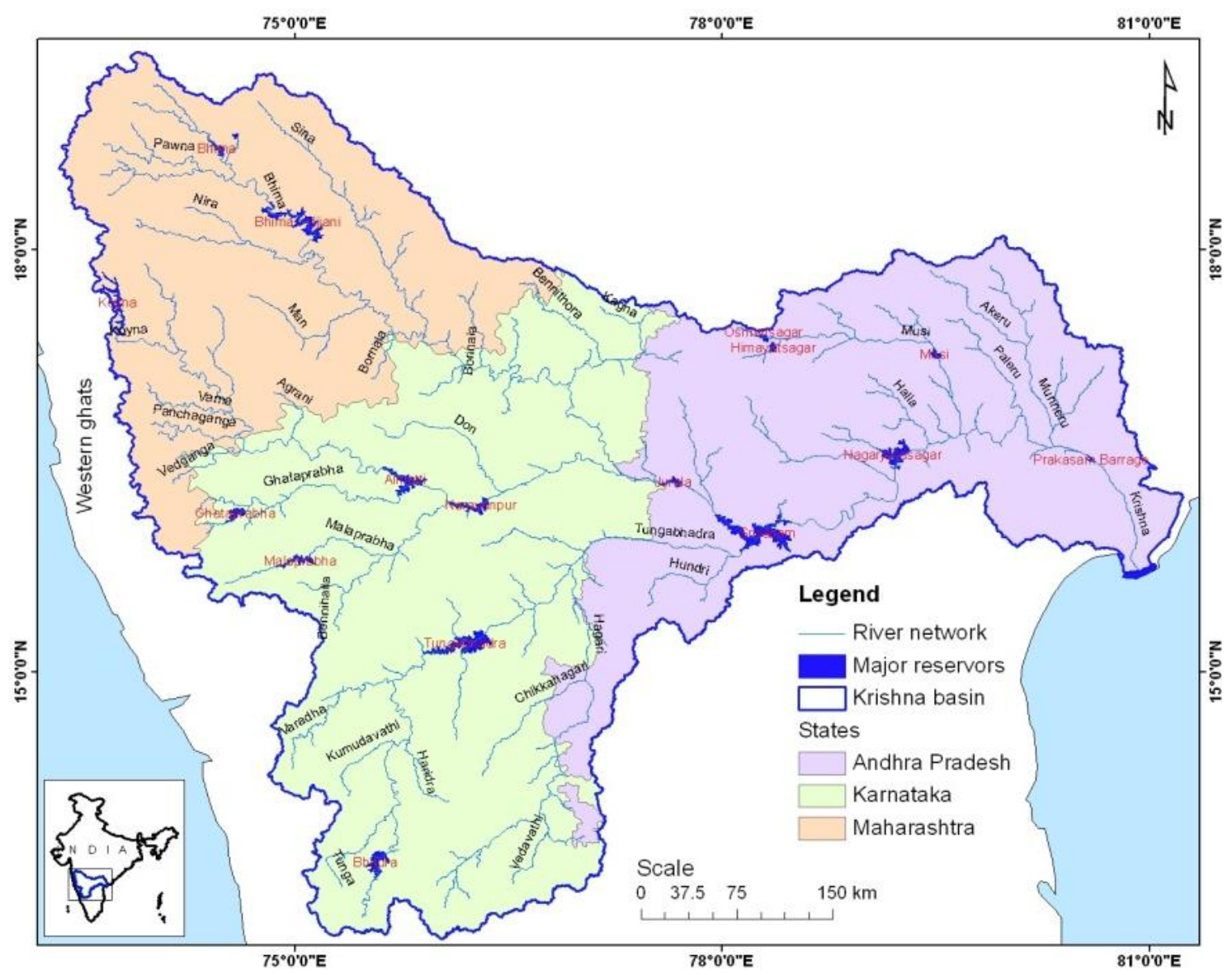

Mainly cropping pattern in three seasons, however during the monsoon (June to mid-December) as kharif, in the post-monsoon dry season (mid-December to March) as Rabi, and dry period (April and May) as summer season. Major command areas most of the farmers grow short duration crops during summer season, other than command areas farmers leave fields fallow. Major crops, Irrigated areas include double cropping of rice, single cropping of sugarcane, chilli, cotton, pulses, fodder grass, and 
some areas of light irrigation of corn, sorghum, sunflower. Rainfed crops include grains (sorghum, millet), pulses (red and green gram, chickpea), and oilseeds (sunflower, groundnut).

Irrigation projects, such as Tungahadra, Nagarjunasagar, bhima-ujjani, Almatti and Prakasam are irrigating about 4,720,000 ha during kharif season. Major canal irrigation schemes occur along each of the three main tributaries in the upper basin, and along the main stream in the lower basin and in the delta (Figure 1). One major hydroelectric project has a limited irrigated command area (Srisailam), and several new projects have large reservoir volumes but as yet small-irrigated command areas (e.g., Alamatti, AL in Figure 1). Minor irrigated systems include small tanks; small, riparian lift schemes, and ground water irrigation. Ground water sources include dug wells, shallow tube wells, and deep tube wells.

\section{Data}

\subsection{MODIS Time Series Data}

The MODIS data for the study was downloaded from calibrated global continuous time-series mega datasets, composed from the individual files from NASA website [11]. The MODIS 2001 every 8 day (Table 1) Terra sensor data in 2 specific bands: band 2 (near infrared), and band 1 (red) are processed for land applications as a MODIS surface reflectance product (MOD09Q1). The MOD09Q1 is computed from MODIS level 3 bands 1-2 (centered at $648 \mathrm{~nm}$, and $858 \mathrm{~nm}$ ). The product is an estimate of the surface reflectance for each band as it would have been measured at ground level if there was no atmospheric scattering or absorption. Initially MODIS data was down loaded in 12-bit (0 to 4,096 levels), and is stretched to 16-bit (0 to 65,536 levels).

Table 1. MODIS Terra 2-band reflectance data characteristics used in this study. Data processing methods adopted from Thenkabail et al., 2005 and Gumma et al., 2010 [9,12].

\begin{tabular}{lccl}
\hline & \multicolumn{3}{c}{ MOD09A1 product ${ }^{1}$} \\
\hline $\begin{array}{c}\text { MODIS } \\
\text { Bands }^{2}\end{array}$ & $\begin{array}{c}\text { Band width } \\
\left(\mathrm{nm}^{3}\right)\end{array}$ & $\begin{array}{c}\text { Band } \\
\text { center } \\
\left(\mathrm{nm}^{3}\right)\end{array}$ & potential application $^{4}$ \\
\hline 1 & $620-670$ & 648 & $\begin{array}{l}\text { Absolute Land Cover Transformation, } \\
\text { Vegetation Chlorophyll } \\
\text { Cloud Amount, Vegetation Land Cover } \\
\text { Transformation }\end{array}$ \\
\hline
\end{tabular}

Note: ${ }^{1}=$ of the 36 MODIS bands, the 7 bands reported here are specially processed for Land studies.

${ }^{2}=$ MODIS bands are re-arranged to follow the electromagnetic spectrum (e.g., blue band

3 followed by green band 4 ).

${ }^{3}=$ nanometers.

${ }^{4}=$ taken from MODIS web site [11].

\subsection{Groundtruth Datasets}

Groundtruth data was collected during October 13-26, 2003 for 144 sample sites covering about 6,500 kilometers of road travel in the Krishna river basin (Figure 2). In addition, groundtruth 
observations were made extensively, while driving, by digitizing on hard-copy topographic maps (1:500,000) obtained from the Survey of India. The Geocover 2000 products were also used as additional groundtruth information in class identification.

Point specific data was collected from $90 \mathrm{~m} \times 90 \mathrm{~m}$ plots and consisted of GPS locations, land use categories, land cover percentages, cropping pattern during different seasons (through farmer interviews), crop types, and watering method (irrigated, rainfed). Samples were obtained within large contiguous areas of a particular land use/land cover (LULC). A stratified-systematic sample design was adopted. The framework was stratified by motorable road network or foot path access where possible- made systematic by locating sites every 5 or 10 kilometers along the road network by vehicle or on foot see [9] for detailed description on the groundtruth methodological approaches.

Figure 2. Groundtruth data point locations in the Krishna river basin. There are 144 groundtruth locations where different land use including irrigation parameters was collected.

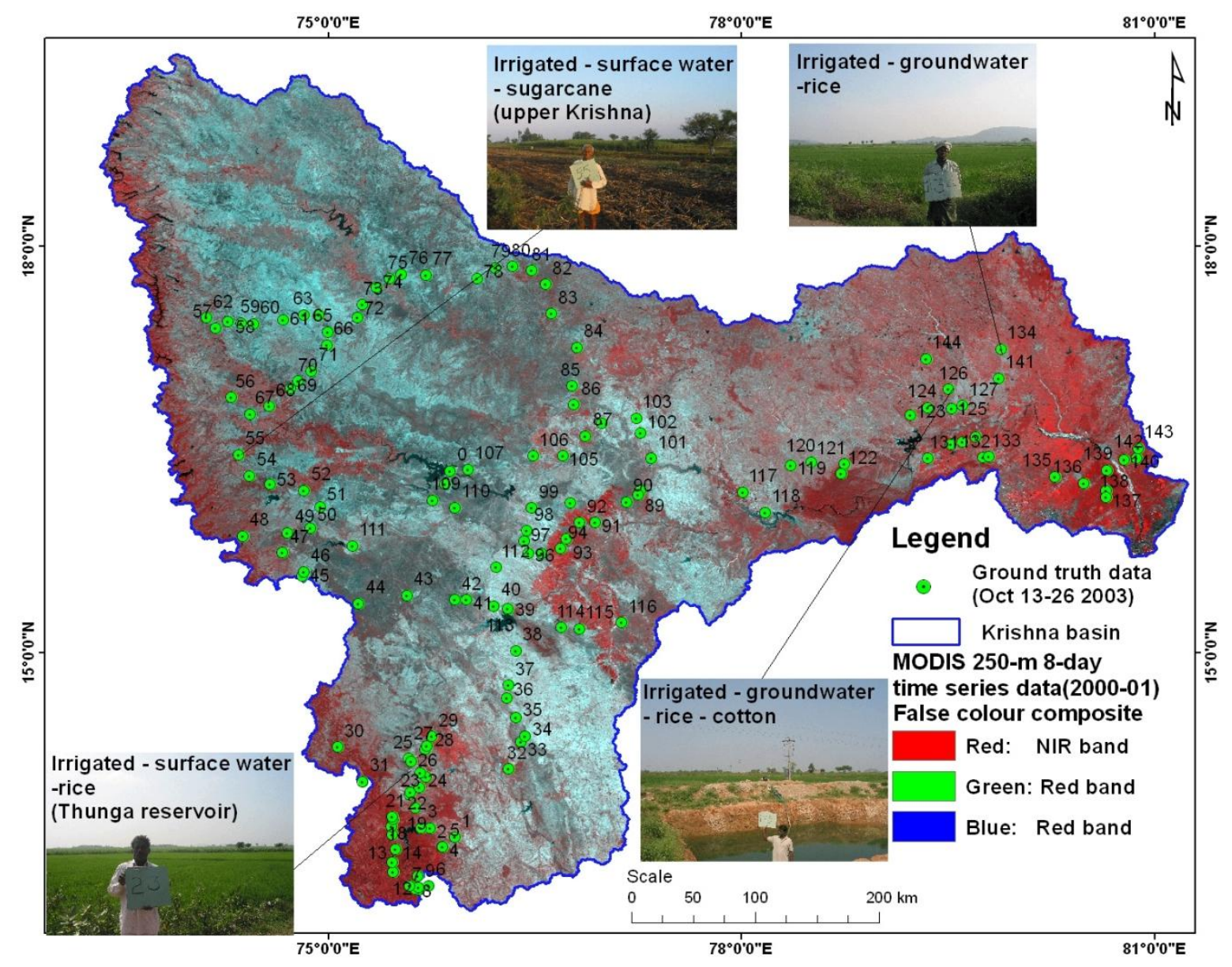

\section{Methods}

\subsection{MODIS NDVI Time-Series Classification}

A time-series of MODIS 8-day composite reflectance images, $250 \mathrm{~m}$ resolution, was obtained for June 1st 2000 to May 31st 2001 (MOD09Q1 data product). The 8-day composite images in the MOD09A1 dataset are free of cost and pre-calibrated [8,11]. The large scene size and daily overpass 
rate of MODIS makes it attractive for large area crop mapping, and NDVI derived from MODIS has high fidelity with biophysical parameters [13]. The composites are created using the maximum NDVI method on the daily MODIS data to minimize cloud effects [14]. The 8-day composite images were downloaded from June 2000 to July 2001. There were three to four 8-day composites per month for a total of forty-five 8-day composites. The 8-day NDVI were stacked into a 46-band NDVI mega-file image (MFI).

Unsupervised classification followed by progressive generalization [15] was used to classify the MODIS time-series and generate generalized classes. The unsupervised ISOCLASS cluster algorithm (ISODATA in ERDAS Imagine 9.2 ${ }^{\mathrm{TM}}$ ) run on the MFI generated an initial 40 classes, with a maximum of 40 iterations and convergence threshold of 0.99 . Though groundtruth data was available at the time of image classification, unsupervised classification was used in order to capture the full range of NDVI time-series over a large area. Use of unsupervised techniques is recommended for large areas that cover a wide and unknown range of vegetation types, and where landscape heterogeneity complicates identification of homogeneous training sites [5,16,17]. Identification of training sites is particularly problematic for small, heterogeneous irrigated areas.

The initial forty classes from the unsupervised classification were merged by user-controlled progressive generalization $[15,18]$ using the class-average MODIS NDVI time-series, groundtruth data (described below), and GeoCover mosaics of Landsat imagery from 1990 and 2000 [9,19]. Classes with similar NDVI time-series and land cover were merged into a single class, and classes showing significant mixing, e.g., continuous irrigated areas and forest, were masked and reclassified using the same ISOCLASS algorithm. Some continuous irrigated areas mixed with forests in the Western Ghats were separated using a $90 \mathrm{~m}$ digital elevation model (DEM) from the Shuttle Radar Topography mission (SRTM) and an elevation threshold of $630 \mathrm{~m}$, determined using the DEM, Landsat imagery and groundtruth data. The merging procedure also known as progressive generalization [15] resulted in a 40-class map and a 9-class map. While class aggregation could have been performed statistically using a Euclidean or other distance measure, we employed a user-intensive method that incorporates both groundtruth and Landsat data in order to avoid lumping classes that might be spectrally similar but have distinct land cover. The NDVI of some classes differed in only one or two months, which would have caused the classes to be merged if an automated similarity index were used to merge the classes.

\subsection{Class Signatures and NDVI-Reflectivity Thresholds}

The class signatures of NDVI are unique spectral properties of a class that can be mapped using NDVI time-series of a class. It is not possible to have "spectral signatures" when single date or a few date images are used as is often the case with most LULC studies. Since near continuous MODIS data has been used in this study, a unique set of LULC class signatures were possible (e.g., Figure 4).

The threshold NDVIs and NDVI signatures over time help us determine the land use type including crop intensity, surface irrigation areas, ground water irrigation areas, rainfed, and rangelands.

1. Onset of a cropping seasons (e.g., Rabi and khariff);

2. Duration of the cropping seasons such as for khariff and Rabi; 
3. Magnitude of the crops during different seasons and years (e.g., drought vs. normal years);

4. End of cropping season (senescence).

In order to illustrate these possibilities, the MODIS CS-NDVI signatures are presented and discussed for a set of distinct classes (Figure 4) and thematically similar classes (Figure 5). The NDVI of forest class 39 and 40 never falls below 0.5 on any date throughout a year and across years (Figure 5) and clearly separates the surface irrigated areas and ground water irrigated areas (Figure 5).

Figure 4. Class spectral signatures for unsupervised 40 classes (MODIS time-series data).

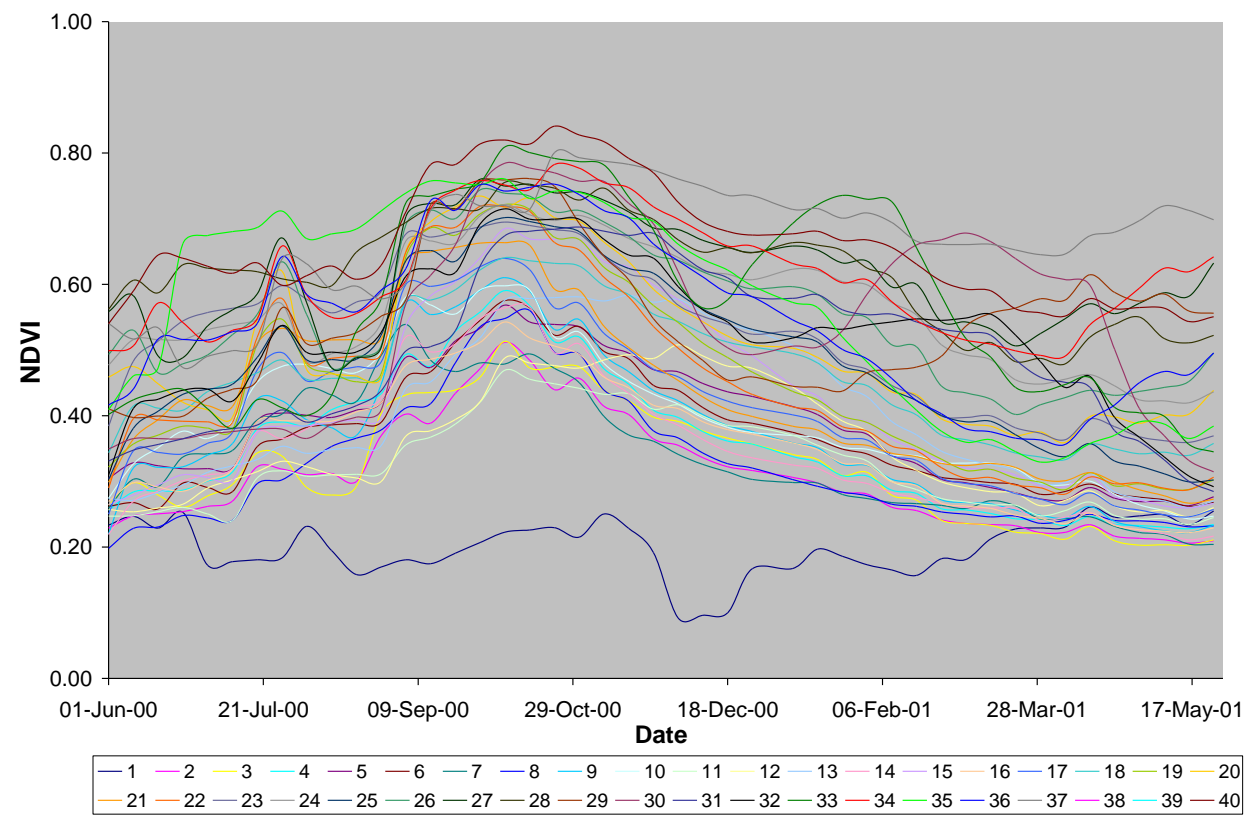

Figure 5. Illustrates MODIS NDVI signatures for 6 spectrally close classes (MODIS time-series data).

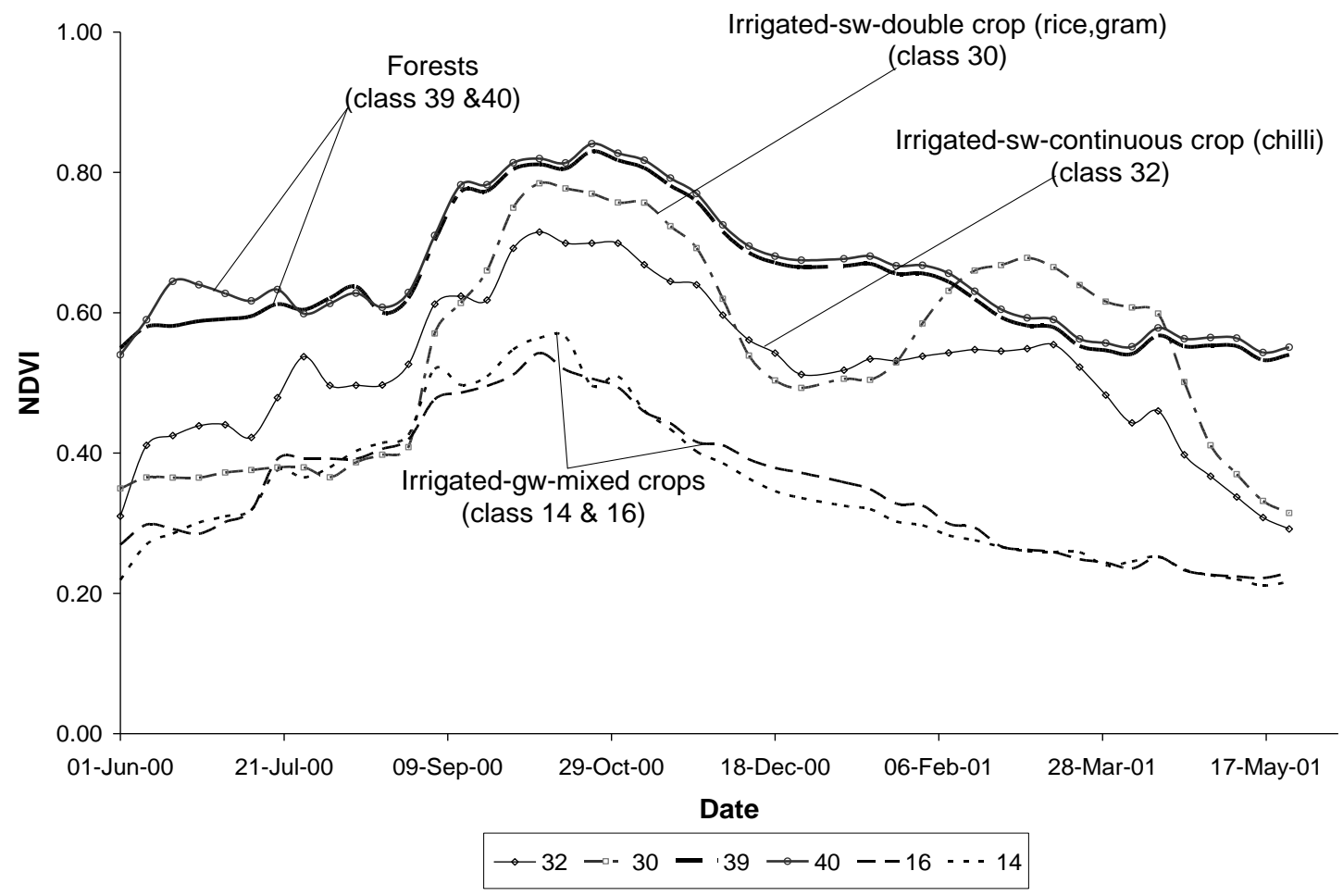




\subsection{Class Lebeling and Sub-Pixel Area Calculations}

Class name has given based on dominance of land use land cover, the land cover fraction coming from groundtruth data. Class labeling is a systematic procedure. First, classes were initially grouped using decision tree, spectral matching technique and verified with Google Earth [20] application provides increasingly comprehensive image coverage of the globe at very high resolution (sub-meter to $30 \mathrm{~m}$ ), allowing the user to zoom into specific areas in great detail, from a base of $30 \mathrm{~m}$ resolution data, based on GeoCover 2000. These methods were adopted from [6,12,18].

Land use land cover accurate estimates of areas from coarse resolution imagery can only be achieved based on sub-pixel areas. Established SPA calculation techniques and methods are described in [12,21]. Final 9 classes represent mix of different land use land cover classes, so the class name represents dominance of a particular cover and not a pure class. Example Class 2 and 3 were classified as rangelands and rainfed areas, which were difficult to separate given their similar vegetation signatures.

\subsection{Irrigated Fractions}

Once accurate mapped irrigated areas, precise areas calculation is very important. Pixels are $250 \mathrm{~m} \times 250 \mathrm{~m}$ and larger than many minor irrigated plots, due to various land use with in $250 \mathrm{~m} \times 250 \mathrm{~m}$, each class in the unsupervised classification has both a name and an irrigated fraction based on groundtruth data. The area irrigated by surface or ground water or tank for a given area of interest is computed from the MODIS classification as Equation (1):

$$
I_{k}=\sum_{i=1}^{n} \alpha_{i, k} A_{i}
$$

where $i_{k}$ is the net area irrigated by source $k$ (surface or ground water), $i$ is the MODIS class number, $n$ is the number of MODIS classes, $\alpha_{i, k}$ is the fraction of class $i$ irrigated by source $k$, and $A_{i}$ is the area covered by MODIS class $i$. This definition is for net irrigated area, which includes all areas irrigated at some point during the annual cropping cycle, and counts double-cropped areas once. The irrigated fractions for each class $\left(\alpha_{i, k}\right)$ were calculated using average of the groundtruth estimates (Table 2). 
Table 2. Land use/ Land cover area fraction Year 2000-2001.

\begin{tabular}{|c|c|c|c|c|c|c|c|c|c|c|c|}
\hline \multirow[b]{2}{*}{ LULC } & \multirow{2}{*}{$\begin{array}{c}\text { Full pixel } \\
\text { area } \\
\text { Area (ha) }\end{array}$} & \multirow[b]{2}{*}{$\mathrm{N}$} & \multicolumn{6}{|c|}{ Vegetation cover percent (mean) } & \multicolumn{2}{|c|}{$\begin{array}{c}\text { Irrigation fraction } \\
\text { percent }\end{array}$} & \multirow[b]{2}{*}{ Major Crops } \\
\hline & & & $\begin{array}{c}\text { Tre } \\
\mathrm{e}\end{array}$ & $\begin{array}{c}\text { Shrub } \\
\mathrm{s} \\
\end{array}$ & $\begin{array}{c}\text { Gras } \\
\mathrm{s}\end{array}$ & $\begin{array}{c}\text { Other } \\
\mathrm{s}\end{array}$ & $\begin{array}{c}\text { Ope } \\
\mathrm{n}\end{array}$ & $\begin{array}{c}\text { Cro } \\
\mathrm{p}\end{array}$ & SW & GW & \\
\hline Class1: Water bodies & 517,782 & - & - & - & - & - & - & - & - & - & \\
\hline $\begin{array}{l}\text { Class2: Shrublands mix with } \\
\text { rangelands }\end{array}$ & $6,521,637$ & 15 & 6.7 & 24.3 & 6.9 & 14.2 & 8.6 & 39.3 & - & - & Grains, oilseeds \\
\hline Class3: Rangelands mix with rainfed & $1,044,788$ & 33 & 0.7 & 1.0 & 22.0 & 19.1 & 15.1 & 42.2 & - & - & Grains, oilseeds, pulses \\
\hline Class4: Rainfed agriculture & $5,910,620$ & 17 & 4.8 & 5.0 & 9.9 & 8.7 & 4.9 & 66.8 & - & - & $\begin{array}{l}\text { Rice, grains, oilseeds, } \\
\text { pulses }\end{array}$ \\
\hline Class5: Rainfed + groundwater & $3,013,915$ & 25 & 2.1 & 1.3 & 3.4 & 7.1 & 10.6 & 75.6 & 5.8 & 94.2 & $\begin{array}{l}\text { Rice, oilseeds, pulses, } \\
\text { grains, cotton, chili }\end{array}$ \\
\hline Class6: Minor irrigated (light/tank) & $2,122,196$ & 6 & 1.5 & 1.1 & 2.9 & 6.3 & 3.7 & 84.5 & 82.3 & 17.7 & $\begin{array}{l}\text { Cotton, grains, oilseeds, } \\
\text { rice }\end{array}$ \\
\hline $\begin{array}{l}\text { Class7: Irrigated-sw + } \\
\text { gw-continuous crops }\end{array}$ & $2,720,606$ & 10 & 2.7 & 2.0 & 1.7 & 2.3 & 2.4 & 88.9 & 31.5 & 68.5 & $\begin{array}{l}\text { Sugarcane, rice, chilli, } \\
\text { cotton }\end{array}$ \\
\hline Class8: Irrigated-sw-double crop & $2,487,827$ & 22 & 1.7 & 3.7 & 1.9 & 2.8 & 2.2 & 87.6 & 89.5 & 10.5 & Rice, grains, pulses \\
\hline Class9: Forests & $2,235,830$ & 12 & 60.2 & 11.2 & 3.0 & 2.7 & 1.6 & 21.3 & - & - & Teak, coffee, aracanut, rice \\
\hline Basin total & $26,575,200$ & $\begin{array}{c}14 \\
0\end{array}$ & 10.0 & 6.2 & 6.5 & 7.9 & 6.1 & 63.3 & & & \\
\hline
\end{tabular}

"N" is no of sample points 


\section{Results and Discussions}

\subsection{LULC Fractions}

Land use land cover fractions calculated from groundtruth data points fall into the class $[9,12,18,21]$. Each LULC class is combination of several land cover types (Table 2). For example in Table 2, in class 8 , cultivable areas $(87.6 \%)$ dominate but there are other land cover types including $1.7 \%$ trees, $3.7 \%$ shrubs, $1.9 \%$ grass, $2.8 \%$ others which include fallows, $2.2 \%$ open area. In these cultivable areas, rice was the dominant crop in kharif season, in the rabi season rice dominant mix with grains. Precise estimation of various thematic areas join classes was calculated as follows (see Table 2):

Cultivable land with in class $8=$ LULC class area for class $\times$ LU\% of cultivable lands $=2,487,827 \times(87.6 / 100)=2,180,318$ ha

Using the same approach, there were 8,669,881 hectares net irrigated areas in 2000-2001 area which includes surface water and ground water irrigation in the basin.

\subsection{Land Use Land Cover Maps and Area Statistics}

The unsupervised classification based on the MODIS NDVI time-series was done initially by obtaining 40 classes then grouped into 9 broad classes which were mapped and this showed clear spectral seperability (Figure 6, Table 3) for the year 2000-2001 and its classes as shown in Figure 6.

Figure 7, nine classes represent a mix of different cover types, the class names indicate dominance of a particular land use and land cover, mix of various land cover such as trees, shrubs, grasses and etc. (Table 2 and 3).Classes identified based on groundtruth data includes GPS referenced digital images and field observations. The classes 2 and 3 included both rangeland and rainfed cropping, which were difficult to separate given their similar vegetation phenology. The land use land cover percentages in the Krishna river basin for 2000-2001 (Table 3) are: Water bodies $1.9 \%$ of the total basin, Shrub lands mix with range lands, fallows is $28.4 \%$, rainfed agriculture is $22.2 \%$ of the basin area, rainfed + ground water irrigation is $11.3 \%$, minor irrigation which include tank and small reservoirs $8 \%$, classes and surface irrigation by canal is $16.3 \%$ and forest $8.4 \%$. 
Figure 6. The irrigated, rainfed, and other LULC and Irrigated area classes in the Krishna River Basin, using MODIS 2000-2001 data.

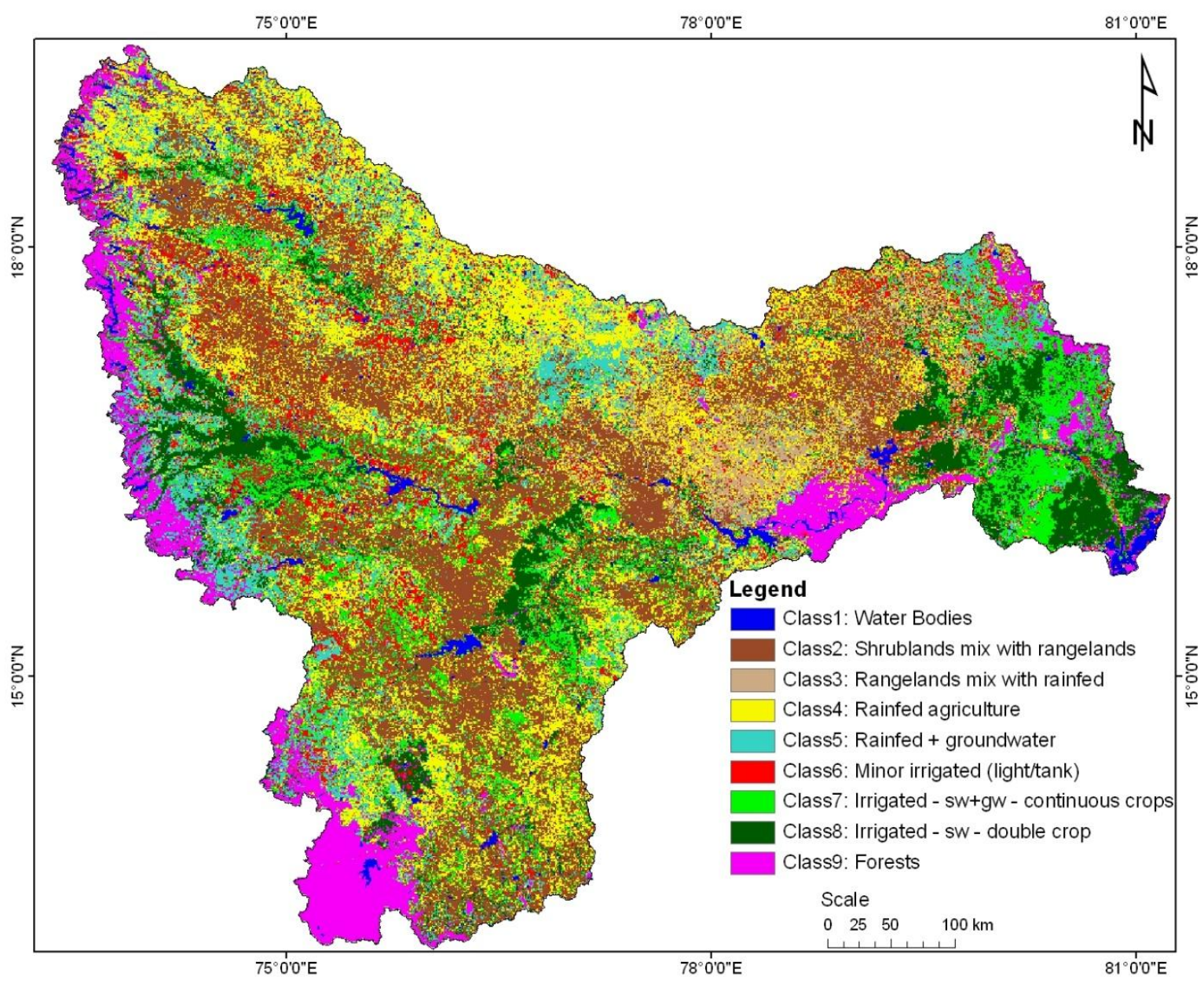


Table 3. Irrigated, rainfed, and other land use/ land cover (LULC) areas.

\begin{tabular}{|c|c|c|c|c|c|c|c|c|}
\hline \multirow{2}{*}{ LULC } & \multirow{2}{*}{$\%$} & \multicolumn{6}{|c|}{ Land use/ land cover area with in the classes (ha) } & \multirow{2}{*}{ Basin total } \\
\hline & & water & Tree & Shrubs & Grass & Others & Crop & \\
\hline Class1: Water bodies & 1.9 & 517,782 & - & - & - & - & - & 517,782 \\
\hline $\begin{array}{l}\text { Class2: Shrublands mix with } \\
\text { rangelands }\end{array}$ & 24.5 & - & 437,083 & $1,585,240$ & 448,825 & $1,487,385$ & $2,563,104$ & $6,521,637$ \\
\hline Class3: Rangelands mix with rainfed & 3.9 & - & 6,962 & 10,443 & 229,753 & 357,162 & 440,467 & $1,044,788$ \\
\hline Class4: Rainfed agriculture & 22.2 & - & 282,660 & 293,304 & 583,059 & 801,460 & $3,950,137$ & $5,910,620$ \\
\hline Class5: Rainfed + groundwater & 11.3 & - & 62,623 & 38,850 & 102,053 & 531,505 & $2,278,884$ & $3,013,915$ \\
\hline Class6: Minor irrigated (light/tank) & 8.0 & - & 32,783 & 23,141 & 61,709 & 212,123 & $1,792,441$ & $2,122,196$ \\
\hline Class7: Irrigated,conjunctive & 10.2 & - & 74,024 & 54,763 & 45,321 & 128,259 & $2,418,239$ & $2,720,606$ \\
\hline $\begin{array}{l}\text { Class8: Irrigated, surface water, double } \\
\text { crop }\end{array}$ & 9.4 & - & 42,312 & 92,091 & 47,290 & 125,816 & $2,180,318$ & $2,487,827$ \\
\hline Class9: Forests & 8.4 & - & $1,346,418$ & 249,751 & 67,097 & 95,427 & 477,136 & $2,235,830$ \\
\hline Basin totals & 100.0 & 517,782 & $2,284,865$ & $2,347,582$ & $1,585,107$ & $3,739,138$ & $16,100,726$ & $26,575,200$ \\
\hline Total Surface Irrigated area (ha) & 16.3 & & & & & & $4,319,928$ & \\
\hline Total Groundwater Irrigated area (ha) & 16.4 & & & & & & $4,349,953$ & \\
\hline Totaol Irrigated areas (ha) & 32.6 & & & & & & $8,669,881$ & \\
\hline
\end{tabular}


By using spectral signatures (Figure 7), this study identified total surface irrigation area (classes 5 to 8 , based on fractions) was $16.3 \%, 4,319,928$ hectares of the basin area and is about the same as the groundwater irrigated area was $16.4 \%, 4,349,953$ hectares of the basin area. The total irrigation area was $32.6 \%, 8,669,881$ hectares of the basin area.

Figure 7. MODIS NDVI signatures over time (for classes in Figure 6) for the irrigated, rainfed, and other LULC classes.

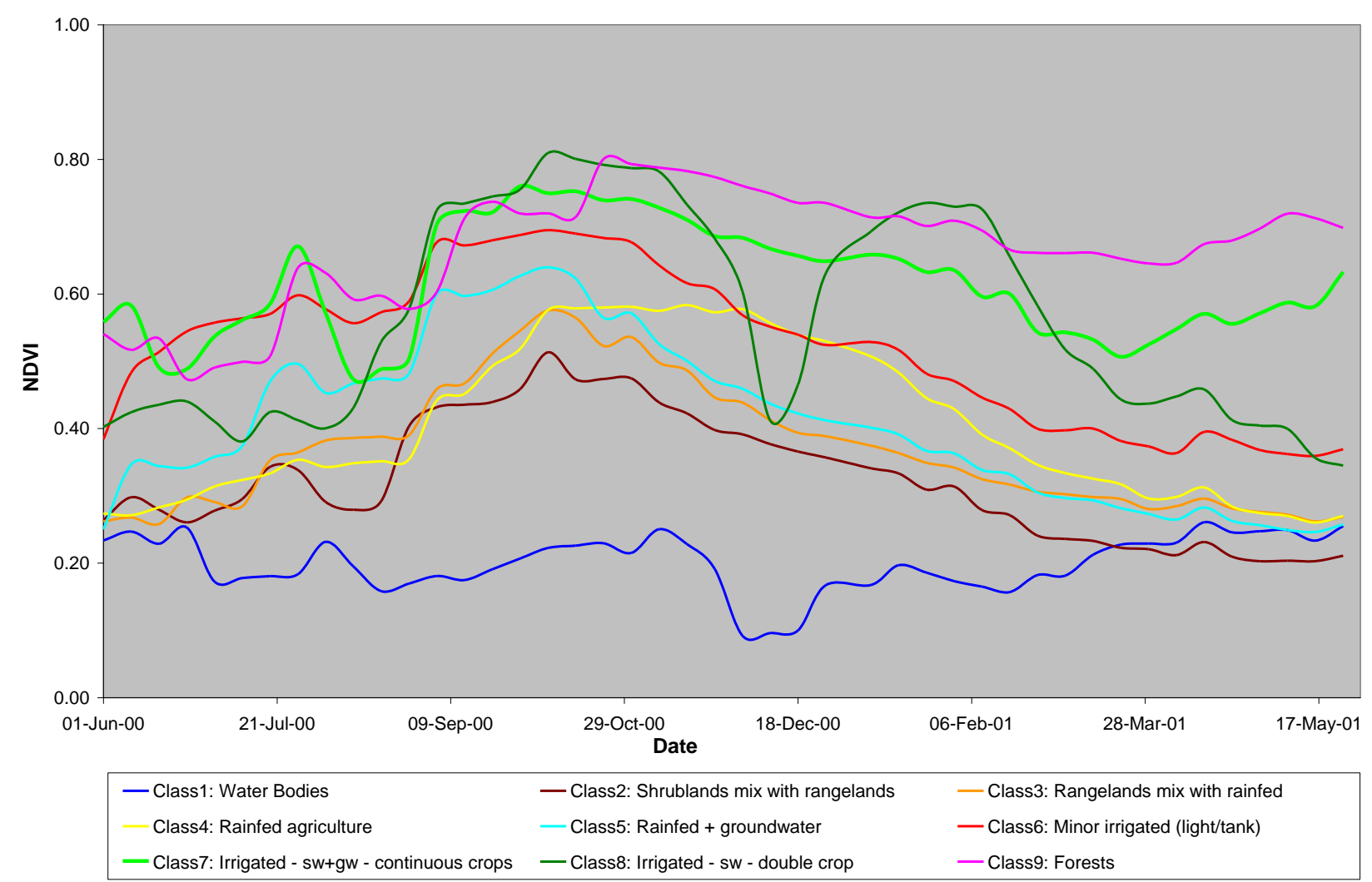

\subsection{Accuracy Assessment}

A qualitative accuracy assessment was performed to check if the irrigated area is classified as irrigated or not, without checking for crop type or type of irrigation. The accuracy assessment was performed using groundtruth data, to derive robust understanding of the accuracies of the datasets used in this study. The groundtruth data was based on an extensive field campaign conducted throughout Krishna basin during kharif season by International Water Management Institute researchers and consisted of 144 points.

Accuracy assessment provides realistic class accuracies (below equations) where land cover is heterogeneous and pixel sizes exceed the size of uniform land cover units (see $[5,9,22]$ ). For this study we had assigned $3 \times 3$ cells of MODIS pixels around each of the groundtruth points to one of six categories : absolutely correct ( $100 \%$ correct), largely correct $(75 \%$ or more correct), correct $(50 \%$ or more correct), incorrect (50\% or more incorrect), mostly incorrect ( $75 \%$ or more incorrect), and absolutely incorrect (100\% incorrect). Class areas were tabulated for a $3 \times 3$-pixel ( 9 pixels) window 
around each groundtruth point. If 9 out of 9 MODIS classes matched with groundtruth data, then it was labeled absolutely correct and so on (Table 4).

The accuracy assessment was carried out using Equations (2) to (4):

$$
\begin{aligned}
& \text { Groundtruth irrigated points } \\
& \text { Accuracy of irrigated area class }=\frac{\text { classified as irrigated area }}{\text { Total number of groundtruth }} \times 100 \\
& \text { points of irrigated area class } \\
& \text { Non - irrigated groundtruth points } \\
& \text { Error of commission for irrigated area class }=\frac{\text { classified as imrigated area }}{\text { Total number of non }- \text { irrigated }} \times 100 \\
& \text { groundtruth points } \\
& \text { Irrigated growndtruth points falling } \\
& \text { Error of omission for irrigated area class }=\frac{\text { on non-irrigated area class }}{\text { Total number of groundtruth ponts of }} \times 100 \\
& \text { irrigated area class }
\end{aligned}
$$

The accuracies and errors of the map of land use land cover are assessed based on intensive groundtruth data (Table 4). First, the 144 groundtruth data points reserved for accuracy assessment from Krishna basin field campaigns were pooled and the accuracy was assessed. The accuracy of the rain-fed croplands varied between $59 \%-61 \%$. However, the errors of omission were $2 \%-8 \%$ and of commission 19\%-36\%. The pooled data from the two sources provided a rain-fed cropland accuracy of $94 \%$ with errors of omission of $5 \%$ and errors of commission of $27 \%$. 
Table 4. Fuzzy accuracy assessment using groundtruth data. Numbers in parentheses indicate the fuzzy correctness percentage. Values in the table indicate the percent of groundtruth windows in each class with a given correctness percentage.

\begin{tabular}{|c|c|c|c|c|c|c|c|c|c|}
\hline \multirow{3}{*}{ MODIS LULC class } & \multirow{3}{*}{$\begin{array}{l}\text { Sample } \\
\text { size }\end{array}$} & \multicolumn{8}{|c|}{ Fuzzy classification accuracy } \\
\hline & & \multirow[t]{2}{*}{$\begin{array}{l}\text { TOTAL } \\
\text { Correct }\end{array}$} & \multirow[t]{2}{*}{$\begin{array}{l}\text { TOTAL } \\
\text { Incorrect }\end{array}$} & $\begin{array}{l}\text { (absolutely } \\
\text { correct) }\end{array}$ & $\begin{array}{l}\text { (mostly } \\
\text { correct) }\end{array}$ & (correct) & (incorrect) & $\begin{array}{l}\text { (mostly } \\
\text { incorrect) }\end{array}$ & $\begin{array}{l}\text { (absolutely } \\
\text { incorrect) }\end{array}$ \\
\hline & & & & $\begin{array}{l}(100 \% \\
\text { correct })\end{array}$ & $\begin{array}{l}\text { ( } 75 \% \text { and above } \\
\text { correct) }\end{array}$ & $\begin{array}{l}\text { (51\% and } \\
\text { above } \\
\text { correct) }\end{array}$ & $\begin{array}{l}(51 \% \text { and } \\
\text { above } \\
\text { incorrect) }\end{array}$ & $\begin{array}{l}\text { (75\% and } \\
\text { above } \\
\text { incorrect) }\end{array}$ & $\begin{array}{l}(100 \% \\
\text { incorrect) }\end{array}$ \\
\hline Class1: Water bodies & 0 & 100 & 0 & 100 & 0 & 0 & 0 & 0 & 0 \\
\hline \multicolumn{10}{|l|}{ Class2: Shrublands mix with } \\
\hline rangelands & 15 & 81 & 19 & 47 & 10 & 23 & 19 & 0 & 0 \\
\hline Class3: Rangelands mix with rainfed & 33 & 76 & 24 & 15 & 31 & 30 & 20 & 3 & 1 \\
\hline Class4: Rainfed agriculture & 17 & 59 & 41 & 45 & 9 & 5 & 3 & 15 & 23 \\
\hline Class5: Rainfed + groundwater & 25 & 63 & 37 & 41 & 5 & 17 & 18 & 1 & 18 \\
\hline Class6: Minor irrigated (light/tank) & 6 & 80 & 20 & 0 & 62 & 18 & 17 & 0 & 4 \\
\hline \multicolumn{10}{|l|}{ Class7: Irrigated-sw + gw-continuous } \\
\hline crops & 10 & 68 & 32 & 46 & 8 & 14 & 14 & 0 & 18 \\
\hline Class8: Irrigated-sw-double crop & 22 & 87 & 13 & 64 & 16 & 7 & 4 & 5 & 5 \\
\hline Class9: Forests & 12 & 87 & 13 & 86 & 1 & 0 & 0 & 0 & 13 \\
\hline Total & 140 & 78 & 22 & 49 & 14 & 12 & 12 & 3 & 9 \\
\hline
\end{tabular}




\subsection{Comparisons with Census Data}

The land use land cover area statistics of the Krishna basin districts was obtained from the Bureau of Economics and Statistics, Andhra Pradesh, Directorate of Economics and Statistics, Karnataka and Department of Agriculture, Maharashtra. The data is obtained at district level from the respective states. This data is fractionalized based on the district wise area covered in the Krishna basin for comparative study with the MODIS data. The fractionized statistics data was compared with the MODIS data for the year 2001. Most of the districts data are matched with the MODIS data for the year 2001, few districts have difference in the statistical data and MODIS data is varied between $-30 \%$ to $30 \%$ (Figure 8 ).

Figure 8. District-wise irrigated area from the MODIS classification compared with the agricultural census.

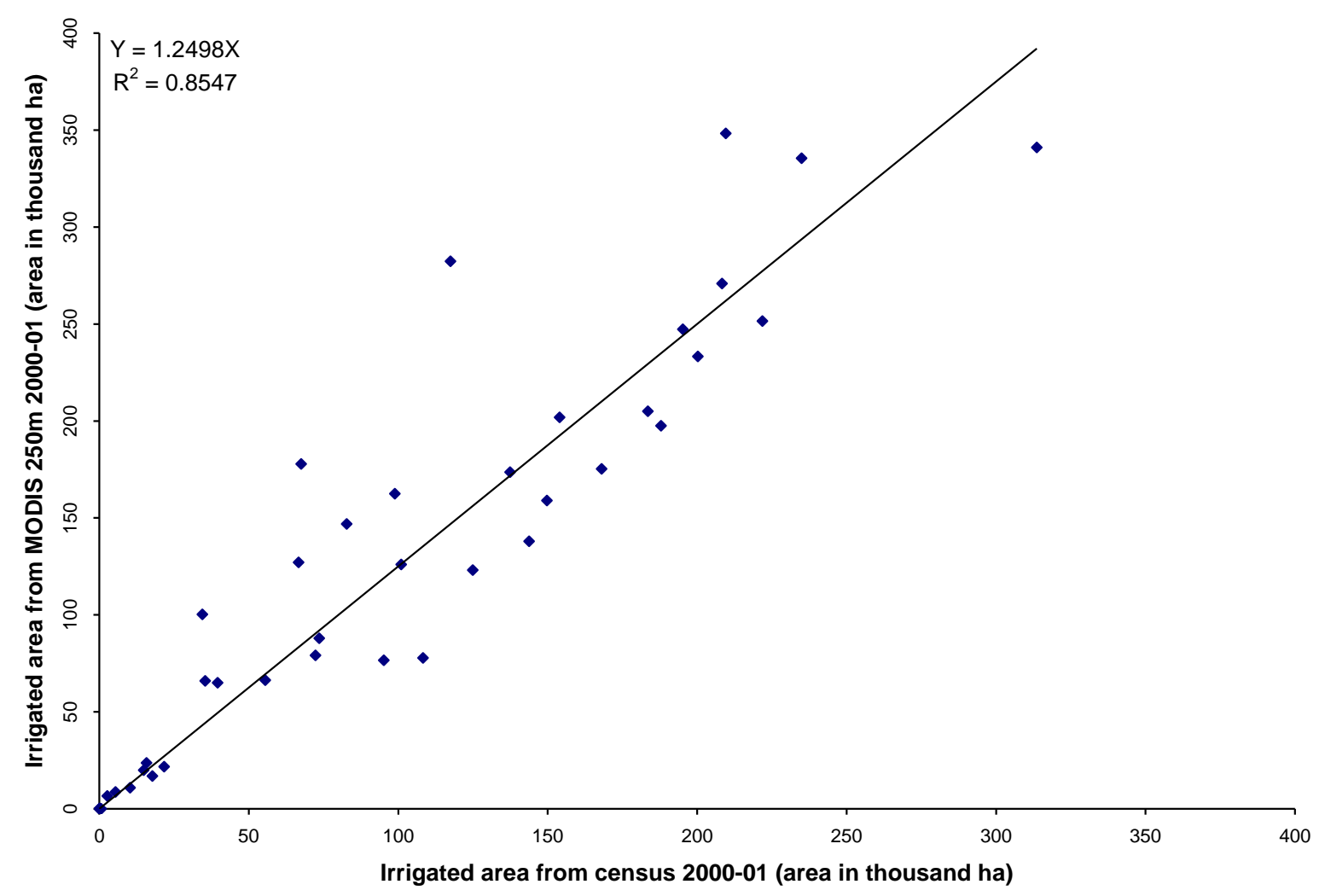

\subsection{Vegetation Phenology of Ground Water and Surface Water Irrigated Areas}

Using spectral signatures, groundtruth data and high resolution images, this study identified all irrigated areas. Mainly ground water and surface water irrigation show good separation in the classification (Figure 7), and district-wise irrigated area from the classification compare well with district-level census data (Figure 8). Two properties of the NDVI time-series allow separation of ground water and surface water irrigation: annual average NDVI, which is a function of the irrigated fraction, and timing on onset of greenness, which is a function of the timing of water availability for vegetation. Annual NDVI in both continuous and double irrigated systems exceeds annual NDVI in ground water systems, reflecting the higher irrigated fraction in areas irrigated with surface water. 
Double cropped (IDBL) and light irrigation (IL) have relatively late onset of greenness, because they use canal water from reservoirs that drain large catchments and take weeks to fill. Minor irrigation and ground water irrigated areas have early onset of greenness because they drain smaller catchments where aquifers and reservoirs fill more quickly (Figure 7). This may not be the case in all years, depending on the relative timing of reservoir filling. In 2001, for instance, the onset of greenness in ground water and surface water systems was similar, which might make discrimination of the two more difficult.

Ground water and surface water irrigated areas also tend to be spatially segregated, which enhances their separability. Ground water irrigation occurs along valley bottoms of second and third order streams or below small reservoirs, while surface irrigation occurs below larger reservoirs draining large catchment areas. Though conjunctive use of both surface and ground water may occur in some areas, such as in minor schemes near small reservoirs, in sugarcane irrigated areas during the dry season, or at the tail end of canals in surface water commands areas, clear separation of the two sources in major canal command areas is difficult, even in the field.

\section{Conclusions}

The paper espoused a vegetation phenological approach, derived using time-series MODIS 250 meter data, in separating ground water irrigation from surface water irrigation based on a study conducted in a large river basin (Krishna, India). Annual average NDVI and timing of onset of greenness allowed the separation of ground water from surface water. The specific land use categories separated were as follows: (a) double cropped and light irrigation have relatively late onset of greenness, because they use canal water from reservoirs that drain large catchments and take weeks to fill, and (b) Minor irrigation and ground water irrigated areas have early onset of greenness because they drain smaller catchments where aquifers and reservoirs fill more quickly. The time-series NDVI phenological signatures were distinctly different in the Krishna basin for: (a) irrigated surface water double crop, (b) irrigated surface water continuous crop, and (c) irrigated ground water mixed crops. Of the basin area of 26,575,200 hecatres, the percentage distribution of various classes were: water bodies $(1.9 \%)$, Shrub lands mix with range lands fallows $(28.4 \%$,) rainfed agriculture $(22.2 \%)$, ground water dominant irrigated areas (11.3\%), minor irrigation including tank and small reservoirs (8\%), and surface irrigation by canal $(19.6 \%)$, and and forests $(8.4 \%)$. The total surface irrigation area (classes 5 to 8 ; see Figure 6) was $16.3 \%, 4,319,928$ hectares of the basin area and is about the same as the groundwater irrigated area was $16.4 \%, 4,349,953$ hectares of the basin area. The total irrigation area was $32.6 \%, 8,669,881$ hectares of the basin area. However the ground water irrigation is at times mixed with rainfed bringing it's area slightly lower than $11.3 \%$. The overall irrigated area from MODIS $250 \mathrm{~m}$ time-series reported here is close to those reported by [4] for Krishna basin which was 9,356,160 hectares produced using Landsat $30 \mathrm{~m}$ in fusion with MODIS $500 \mathrm{~m}$ data.

\section{Acknowledgements}

The authors would like to gratefully acknowledge the support of the International Water Management (IWMI) and Australian Centre for International Agriculture Research (ACIAR). We would like to also thank Paul Pavelic, Senior Researcher, IWMI, and Hyderabad who was encouraging 
during initial stage. The authors would like to thank Sreedhar Acharya for providing census data. The MODIS data were provided through Earth Observing system data and Information System (EOSDIS), so we would like to thank them for this wonderful service. The paper is not internally reviewed by the US Geological Survey (USGS), and the opinions expressed in the paper are those of the authors and not those of USGS.

\section{References}

1. Bhutta, M.N.; van der Velde, E.J. Equity of water distribution along secondary canals in Punjab, Pakistan. Irrig. Drain. Syst. 1992, 6, 161-177.

2. Gaur, A.; Biggs, T.W.; Gumma, M.K.; Parthasaradhi, G.; Turral, H. Water scarcity effects on equitable water distribution and land use in Major Irrigation Project-A Case study in India. J. Iirrig. Drain. Eng. 2008, 134, 26-35.

3. Shah, T.; Molden, D.; Sakthivadivel, R.; Seckler, D. The Global Ground Water Situation: Overview of Opportunities and Challenges; International Water Management Institute: Colombo, Sri Lanka, 2000.

4. Velpuri, N.M.; Thenkabail, P.S.; Gumma, M.K.; Biradar, C.B.; Noojipady, P.; Dheeravath, V.; Yuanjie, L. Influence of resolution in irrigated area mapping and area estimations. Photogramm. Eng. Remote Sens. 2009, 75, 1383-1395.

5. Biggs, T.W.; Thenkabail, P.S.; Gumma, M.K.; GangadharaRao, T.P.; Turral, H. Vegetation phenology and irrigated area mapping using combined MODIS time-series, ground surveys, and agricultural census data in Krishna River Basin, India. Int. J. Remote Sens. 2006, 27, 21.

6. Gumma, M.K.; Thenkabail, P.S.; Fujii, H.; Namara, R. Spatial models for selecting the most suitable areas of rice cultivation in the Inland Valley Wetlands of Ghana using remote sensing and geographic information systems. J. Appl.Remote Sens. 2009, 3, 033537.

7. Sellers, P.J.; Schimel, D. Remote sensing of the land biosphere and biogeochemistry in the EOS era: science priorities, methods and implementation. Global Planet. Change 1993, 7, 279-297.

8. King, M.D.; Closs, J.; Spangler, S.; Greenstone, R.E. EOS Data Products Handbook, Version 1; NASA Goddard Space Flight Center: Greenbelt, MD, USA, 2003.

9. Thenkabail, P.S.; Schull, M.; Turral, H. Ganges and Indus river basin land use/land cover (LULC) and irrigated area mapping using continuous streams of MODIS data. Remote Sens. Environ. 2005, 95, 24.

10. U.S. Geological Survey (USGS). Shuttle Radar Topography Mission (SRTM) "Finished" 3-arc second SRTM Format Documentation. Available online: http:/gcmd.nasa.gov/records/ GCMD_DMA_DTED.html (accessed on 6 November 2006).

11. National Aeronautics and Space Administration (NASA). Moderate Resolution Imaging Spectrometer (MODIS). Available online: http://modis.gsfc.nasa.gov/data/dataprod/index.php (accessed on 21 August 2007). 
12. Gumma, M.K.; Thenkabail, P.S.; Iyyanki, M.V.; Velpuri, N.M.; GangadharaRao, T.P.; Dheeravath, V.; Biradar, C.M.; Nalan, A.S.; Gaur, A. Changes in agricultural cropland areas between a water-surplus year and water-deficit year impacting food security determined using MODIS $250 \mathrm{~m}$ time-series data and spectral matching techniques in the Krishna River Basin (India). Int. J. Remote Sens. 2011, doi: 10.1080/01431161003749485.

13. Huete, A.; Didan, K.; Miura, T.; Rodriguez, E. Overview of the radiometric and biophysical performance of the MODIS vegetation indices. Remote Sens. Environ. 2002, 83, 195-213.

14. Holben, B.N. Characteristics of maximum-value composite images from temporal AVHRR data. Int. J. Remote Sens. 1986, 7, 1417-1434.

15. Cihlar, J.; Xiao, Q.; Beaubien, J.; Fung, K.; Latifovic, R. Classification by progressive generalization: A new automated methodology for remote sensing multichannel data. Int. J. Remote Sens. 1998, 19, 2685-2704.

16. Achard, F.; Estreguil, C. Forest classification of Southeast Asia using NOAA AVHRR data. Remote Sens. Environ. 1995, 54, 198-208.

17. Cihlar, J. Land cover mapping of large areas from satellites: status and research priorities. Int. J. Remote Sens. 2000, 21, 1093-1114.

18. Thenkabail, P.S.; Biradar, C.M.; Noojipady, P.; Dheeravath, V.; Li, Y.; Velpuri, M.; Gumma, M.; Gangalakunta, O.R.P.; Turral, H.; Cai, X.; Vithanage, J.; Schull, M.A.; Dutta, R. Global irrigated area map (GIAM), derived from remote sensing, for the end of the last millennium. Int. J. Remote Sens. 2009, 30, 3679-3733.

19. Tucker, C.; Grant, D.; Dykstra, J. NASA's global orthorectified Landsat data set. Photogramm. Eng. Remote Sens. 2005, 70, 313-322.

20. GoogleEarth. Available online: http://www.google.com/earth/index.html (accessed on 17 October 2007).

21. Thenkabail, P.S.; GangadharaRao, P.; Biggs, T.; Krishna, M.; Turral, H. Spectral matching techniques to determine historical land use/land cover (LULC) and irrigated areas using time-series AVHRR pathfinder datasets in the Krishna River Basin, India. Photogramm. Eng. Remote Sens. 2007, 73, 12.

22. Gopal, S.; Woodcock, C. Theory and methods for accuracy assessment of thematic maps using fuzzy sets. Photogramm. Eng. Remote Sens. 1994, 60, 8.

(C) 2011 by the authors; licensee MDPI, Basel, Switzerland. This article is an open access article distributed under the terms and conditions of the Creative Commons Attribution license (http://creativecommons.org/licenses/by/3.0/). 